\title{
Infection Control Measures in Dental Clinics during Coronavirus Disease-19 Pandemic in Kingdom of Saudi Arabia: A Pilot Study
}

\author{
Rawa Kamal Abdelrahim ${ }^{1 *}$, Husham Abu Elgasim Abdoun ${ }^{2}$, Pradeep Koppolu ${ }^{1}$, Lingam Amara Swapna ${ }^{3}$ \\ ${ }^{1}$ Department of Preventive Dental Sciences, College of Dentistry, Dar Al Uloom University, Riyadh, Saudi Arabia; ${ }^{2}$ Medical \\ Affairs of Saudi Border Guard, Riyadh, Saudi Arabia; ${ }^{3}$ Department of Surgical and Diagnostic Sciences, College of Dentistry, \\ Dar Al Uloom University, Riyadh, Saudi Arabia
}

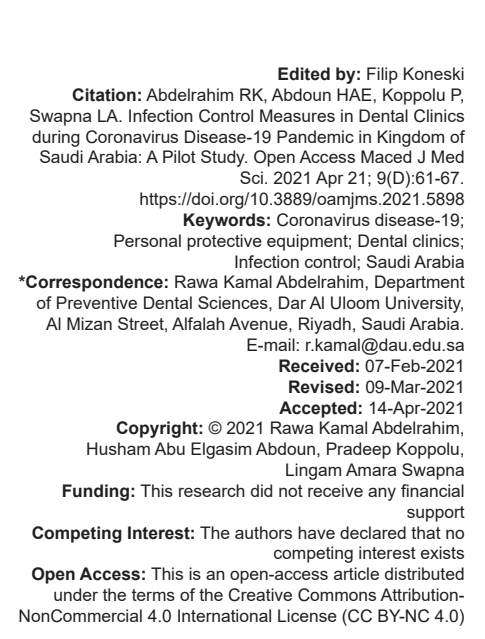

\begin{abstract}
BACKGROUND: Coronavirus disease (COVID)-19 is an infectious respiratory disease causing different symptoms ranging from mild to more complicated cases. In dental clinics, there is a potential risk of cross-infection between dental health worker and patients. Therefore, new infection prevention measures have been recommended to minimize spread of COVID-19 in dental clinics.

AIM: The aim of this study is to get an insight into the infection control measures followed by dentists and modification done in personal protective equipment (PPE) to combat spread of infection during COVID-19 in Kingdom of Saudi Arabia.

METHODS: A cross-sectional data using online Google survey. The sample included dentists working in either private or government from different regions in Kingdom of Saudi Arabia. Chi-square test was used to investigate the association between categorical variables $(p<0.05)$

RESULTS: Seventy dentists included in the study of which $40 \%$ are working in Riyadh. Dental clinics are undertaken respiratory triage and reduce number of patients in waiting area $(91 \%$ and $98 \%$, respectively). Increased usage of PPE (head cap, face shield, and N95 mask) during the pandemic was observed in the study sample $(p=0.001)$. Working hours and number of patients were reduced during COVID-19.

CONCLUSION: Evidence shows that majority of dentists working in KSA are following recommended measures to minimize the spread of COVID-19. Some dentists modified their PPE during the pandemic. However, further research is required to investigate adherence to infection control measures by dentists.
\end{abstract}

\section{Introduction}

By the end of 2019, an emerging disease was detected named as coronavirus (CoV) disease (COVID-19) [1], [2]. The disease is caused by severe acute respiratory syndrome CoV-2 (SARS-CoV) which belongs to the family of CoVs. The CoV is known to cause other respiratory infections such as SARS-CoV and Middle East respiratory syndrome (MERS-CoV) [3]. The virus was reported to be from zoonotic origin meaning that they can be transmitted from animals to humans [4], [5].

The first cases were identified in Wuhan, China, in December 2019 as an acute respiratory illness of unknown etiology [6], [7]. The disease continued spreading to rest of China and to other countries leading the World Health Organization to announce it as "public health emergency of international concern" in January 2020 [8]. By March 11, 2020, due to the rapid spread of the diseases and the increasing numbers of cases and deaths worldwide, COVID-19 was considered as pandemic [2], [9].
COVID-19 has no specific symptoms; it can range from asymptomatic or mild symptoms to severe and critical symptoms [10]. The most commonly reported signs and symptoms are fever, respiratory symptoms (shortness of breath and cough) and fatigue. Less reported symptoms are headache, nausea or vomiting, sneezing, diarrhea, and loss of taste and smell [4], [11], [12], [13]. In addition to that, the virus has been reported to cause more advanced and fatal cases including pneumonia and organ failure [14], [15].

According to evidence, COVID-19 has several transmission modes [10]. It can occur directly when someone is in close distance with infected person, through the inhalation of respiratory droplets produced during coughing, sneezing, or talking to the infected person. The indirect mode of transmission through contacting or touching fomite [16], [17], [18], or through airborne transmission by inhalation of air suspended particles released during aerosol-generating procedures [17], [19].

Dental settings carry a potential risk of cross-infection between patient and dental health worker [20]. Transmission in dental practice may occur 
by contaminated aerosols generated during dental procedures requiring the use of high-speed handpiece and ultrasonic scaler [21]. The dental health workers usually work in close proximity to the patient, this may lead to nasal or conjunctival mucosal contamination with droplets. In addition, transmission may occur due to contact with contaminated surfaces or instruments in dental clinic [22], [23]. Based on COVID-19 modes of transmission and due to the nature of dental procedures, new guidelines and infection prevention measures have been recommended by the Ministry of Health of Kingdom of Saudi Arabia [24].

The aim of the study is to investigate the infection control measures followed by dentists and modification done in personal protective equipment (PPE) to combat spread of infection during COVID-19 pandemic in Kingdom of Saudi Arabia.

\section{Materials and Methodology}

\section{Data source and collection}

This cross-sectional study was conducted among dentists working in Kingdom of Saudi Arabia between June 7, 2020, and July 4, 2020. The survey assesses the infection control measures and modification done in dental clinics during COVID-19 pandemic. The study was targeted on general dentists, specialists, and consultants, working either in private, government, or university dental clinics. Interns and board students were excluded from the study. To ensure inclusion of a representative sample, random clinics were selected from different provinces (Central, Northern, Southern, Eastern, and Western provinces). The clinics/hospitals were selected randomly based on a Google search for each province separately. The clinics were contacted through phone call to invite them to take part in the study. In case of dental centers, the permission of survey distribution to dentist was obtained from the administration (clinical manager) or from the dentist directly if it was private dental clinic. The data were collected using the Google Forms and a link of the structured questionnaire was sent to selected clinics.

The questionnaire was developed based on the cross-infection preventive measures published by Ministry of Health "Dental Emergency Protocol during COVID-19 Pandemic" and "Guidelines for reopening June 5" [24]. The survey was in English language using multiple-choice and checkboxes questions. It consisted of 23 questions, the first part aimed to inquire about demographics (age, sex, and province) and about professional-related information (years of experience, type of practice, and designation). The respondents are to select from the multiple choices provided in each questions. The second part of survey was multiple-choice questions as well, inquiring about clinic activity before and during COVID-19, for example, working hours, number of patients treated daily, and procedure provided. Finally, the third section focused on questions related to cross-infection protocols carried out before and during COVID-19 (modified from Consolo, Bellini) [25]. These questions included checkboxes allowing the respondent to choose more than 1 answer. One question was added to identify difficulties faced by dentist during the pandemic "During the COVID-19 restrictions did you find difficulties in obtaining PPE and other infection control materials?" and they were asked to specify. A short overview and aim of the study were explained at the beginning of the survey as well as verbally during the phone call. The participants were also informed that they responses are anonymous and information will remain confidential.

\section{Statistical analysis}

Statistical analysis was used performed using Statistical Package for the Social Sciences version 20 (SPSS 20). For the demographic and professional related data, we used descriptive analysis (percentage and frequency). To investigate the association between categorical variables, Chi-square test was used (statistical significance set at $p<0.05$ ). On the other hand to find the modification between post and pre COVID-19 in PPE we used other variables. McNemar statistical test was performed to determine if there are any differences on the dichotomous dependent variable between two related groups.

\section{Results}

Data from 70 dentists working in Saudi Arabia were analyzed, among which $68.6 \%$ were male (Table 1). Thirty-six of the participants were specialists (51.4\%), 27 were general dentists, and only 7 were consultants. Most of participants located in the Central province $(40 \%)$ and higher percentage were working in private clinics (41.1\%).

Table 2 presents the association between infection prevention measures followed by dental clinics during COVID-19 and other variables.

When comparing number of working hours and number of treated cases during and pre-COVID-19 time (Table 3), Wilcoxon sign-rank test revealed that there is a statistically significant reduction in both variables ( $p=0.039$ and $p=0.001$, respectively).

Chi-square analysis showed a statistically significant association between PPE and types of clinics, but not for other parameters. The government dental practice commonly used surgical mask (89\%), 
face shield (86\%), and disposable gown (86\%) type of PPE while performing any dental procedure during COVID-19. The private dental practice frequently used face shield (100\%) and disposable gowns (97\%) type of PPE. Whereas university clinic/hospital frequently used disposable gowns (92\%) type of PPE. Among all the types of dental practices, protective suits and shoe cover were least used $(<20 \%)$, Table 4.

The differences in PPE usage before and during COVID-19 are presented in Table 5. It was observed increased use of head cap during COVID-19 to $73 \%$ compared to $37 \%$ before COVID-19 ( $p=0.001)$. Similarly, eye protection (face shield) displays statistically significant ( $p=0.001$ ) higher usage during COVID-19. A parallel result noted in case of N95 mask usage and

Table 1: Distribution of demographics and professional-related data of the study subjects

\begin{tabular}{lll}
\hline Group & Frequency & Percentage \\
\hline Age group & 32 & \\
$<35$ years old & 28 & 45.7 \\
35-45 years old & 9 & 40 \\
$45-54$ years old & 1 & 12.86 \\
$>54$ years old & 22 & 1.43 \\
Gender & 48 & 31.4 \\
$\quad$ Female & & 68.6 \\
Male & 28 & 40 \\
Province & 10 & 14.3 \\
Central & 11 & 15.7 \\
Eastern & 13 & 18.6 \\
Northern & 8 & 11.4 \\
Southern & & \\
Western & 7 & 10 \\
Designation & 27 & 38.6 \\
Consultant & 36 & 51.4 \\
General dentist & & \\
Specialist & 28 & 40 \\
Type of dental practice & 29 & 41.4 \\
Government & 13 & 18.6 \\
Private clinic & & \\
University clinic/hospital & 20 & 28.6 \\
Experience & 22 & 24.3 \\
>15 years & 17 & 15.7 \\
1-5 years & 11 & \\
11-15 years & & \\
6-10 years & &
\end{tabular}

disposable gowns which was statistically significant $(p=0.001)$. However, differences were not significant in case of surgical gloves and goggles.

\section{Discussion}

The new emerging infectious diseases COVID19 can lead to a range of different symptoms including complicated cases. The disease can be transmitted from one individual to another through various routes, it spreads through droplets, airborne transmission, or fomites [10]. In dental clinics, there is a risk of cross-infection between dental health worker and patients which may occur through direct contact with contaminated body fluids or airborne transmission [26]. Increased risk of COVID-19 transmission in dental clinics is because of several factors. First, the dentists work in the close proximity to the patients. Second, several dental procedures generate aerosols that stay for long time in the air. Finally, contaminated surfaces and instruments play a very crucial role in disease transmission. Therefore, having a strict preventive measures and adequate PPE will minimize the cross-infection in dental settings [22], [27]. Due to the unique nature of the dental procedures and the different transmission routes of corona virus, there was a need to articulate new recommendations for dental clinics to reduce the spread of diseases [24].

This study gives an insight into the infection control measures and modification done in dental clinics to prevent the spread of COVID-19. Data were collected from the dentists working in different regions in Saudi Arabia using an online questionnaire.

Table 2: Association of types of infection control and prevention measures following in the clinic during COVID-19 among different parameters

\begin{tabular}{|c|c|c|c|c|c|c|c|c|}
\hline Group & $\begin{array}{l}\text { Patient screened } \\
\text { for COVID-19 triage } \\
\text { question }\end{array}$ & $\begin{array}{l}\text { Patient and staff's } \\
\text { body temperature }\end{array}$ & $\begin{array}{l}\text { Reduced number of patients } \\
\text { in the waiting room }\end{array}$ & $\begin{array}{l}\text { Hand } \\
\text { sanitization }\end{array}$ & PPE & $\begin{array}{l}\text { Disinfection of } \\
\text { waiting area and } \\
\text { facility areas }\end{array}$ & $\begin{array}{l}\text { Fumigating the } \\
\text { clinic }\end{array}$ & $p$-value \\
\hline \multicolumn{9}{|l|}{ Age } \\
\hline$<35$ years old & 29 & 31 & 28 & 29 & 29 & 25 & 12 & \multirow[t]{4}{*}{0.954} \\
\hline$>54$ years old & 1 & 1 & 1 & 1 & 1 & 0 & 0 & \\
\hline 35-44 years old & 26 & 27 & 27 & 25 & 23 & 20 & 11 & \\
\hline $45-54$ years old & 8 & 9 & 8 & 9 & 9 & 9 & 3 & \\
\hline \multicolumn{9}{|l|}{ Sex } \\
\hline Female & 21 & 22 & 19 & 22 & 21 & 16 & 10 & \multirow[t]{2}{*}{0.309} \\
\hline Male & 43 & 46 & 45 & 42 & 41 & 38 & 16 & \\
\hline \multicolumn{9}{|l|}{ Province } \\
\hline Central & 25 & 28 & 27 & 25 & 24 & 22 & 10 & \multirow[t]{5}{*}{0.113} \\
\hline Eastern & 10 & 10 & 10 & 10 & 10 & 8 & 6 & \\
\hline Northern & 10 & 10 & 7 & 10 & 10 & 8 & 5 & \\
\hline Southern & 12 & 13 & 13 & 12 & 11 & 10 & 2 & \\
\hline Western & 7 & 7 & 7 & 7 & 7 & 6 & 3 & \\
\hline \multicolumn{9}{|l|}{ Designation } \\
\hline Consultant & 5 & 7 & 6 & 7 & 6 & 5 & 1 & \multirow[t]{3}{*}{0.486} \\
\hline General dentist & 25 & 26 & 23 & 26 & 25 & 22 & 8 & \\
\hline Specialist & 34 & 35 & 35 & 31 & 31 & 27 & 17 & \\
\hline \multicolumn{9}{|c|}{ Type of dental practice } \\
\hline Government & 24 & 26 & 26 & 23 & 24 & 21 & 9 & \multirow[t]{3}{*}{0.118} \\
\hline Private clinic & 28 & 29 & 26 & 28 & 25 & 20 & 10 & \\
\hline $\begin{array}{l}\text { University clinic/ } \\
\text { hospital }\end{array}$ & 12 & 13 & 12 & 13 & 13 & 13 & 7 & \\
\hline \multicolumn{9}{|l|}{ Experience } \\
\hline$>15$ years & 13 & 12 & 11 & 12 & 12 & 11 & 3 & \multirow[t]{5}{*}{0.227} \\
\hline $1-5$ years & 15 & 18 & 18 & 16 & 15 & 16 & 9 & \\
\hline $11-15$ years & 15 & 17 & 17 & 16 & 15 & 12 & 4 & \\
\hline $6-10$ years & 21 & 21 & 18 & 20 & 20 & 15 & 10 & \\
\hline $2-3$ years & 15 & 15 & 15 & 14 & 14 & 10 & 3 & \\
\hline
\end{tabular}


The findings of this study revealed that majority of dental clinics are following the preventive measures recommended. About $91 \%$ of clinics screened patients for respiratory triage (travel history and primary contact in the past 14 days) and $98 \%$ measured temperature for both patients and staffs. However, $91 \%$ of the clinics reduced the number of patients in the waiting area, this could be explained by the fact that some clinics were providing only emergency treatments. Moreover, reduced number of patients treated daily during

Table 3: Comparison of average working hours in clinic and average number of new and old patients treated daily before and after COVID-19

\begin{tabular}{lllll}
\hline Group & $\mathrm{N}$ & Mean rank & $\mathrm{Z}$ & $\mathrm{p}$-value \\
\hline $\begin{array}{l}\text { Post-COVID-19-pre-COVID-19 } \\
\text { (average working hours in clinic) }\end{array}$ & & & & \\
$\quad$ Negative ranks & 23 & 22 & -2.069 & $0.039^{*}$ \\
$\quad$ Positive ranks & 15 & 15.67 & & \\
$\quad$ Ties & 32 & & & \\
$\begin{array}{l}\text { Post-COVID-19-pre-COVID-19 } \\
\text { (average number of new and old }\end{array}$ & & & & \\
patients treated daily) & 35 & 19.71 & -4.29 & $0.001^{*}$ \\
$\quad$ Negative ranks & 4 & 22.5 & & \\
$\quad$ Positive ranks & 31 & & & \\
$\quad$ Ties & & & & \\
\hline
\end{tabular}

COVID-19 may indicate that clinics are having less patients in waiting area as well as having more time to ventilate and disinfecting the clinics between patients.

Regarding PPE results showed statistical difference in the type of PPE used by dentist pre and during the pandemic. There was variation in type of PPE used by dentist, especially across different types of dental clinics. Overall, there was a noticeable increase in the use of face shield (90\% during COVID-19 compared to $47 \%$ pre-COVID), head caps increases to $73 \%$ ), N95 mask (13\% before COVID-19 to $47 \%$ after COVID), and disposable gowns (before COVID-19 64\%-91\%). Whereas, no differences were detected in the use of surgical gloves and goggles. A similar observation was reported in a study conducted in Modena and Reggio Emilia, Italy, investigating the impact of COVID-19 pandemic on dentist's behavior and practically on daily clinical practice. The study reported that $77 \%$ of the sample $(n=356)$ have modified the PPE used during COVID-19 [25]. As for preventive measures during clinical activity, 86\% screened for COVID-19 through

Table 4: Association of usage different types of PPE while performing any dental procedure during COVID-19 among different parameters

\begin{tabular}{|c|c|c|c|c|c|c|c|c|c|c|c|}
\hline Group & $\begin{array}{l}\text { Surgical } \\
\text { mask }\end{array}$ & $\begin{array}{l}\text { Examination } \\
\text { gloves }\end{array}$ & $\begin{array}{l}\begin{array}{l}\text { Surgical } \\
\text { gloves }\end{array} \\
\end{array}$ & $\begin{array}{l}\text { Head } \\
\text { cap }\end{array}$ & $\begin{array}{l}\text { Eye protection } \\
\text { (face shield) }\end{array}$ & $\begin{array}{l}\text { Eye protection } \\
\text { (goggles) }\end{array}$ & $\begin{array}{l}\text { N95 } \\
\text { mask }\end{array}$ & $\begin{array}{l}\text { Disposable } \\
\text { gowns }\end{array}$ & $\begin{array}{l}\text { Protective } \\
\text { suits }\end{array}$ & $\begin{array}{l}\text { Shoe } \\
\text { cover }\end{array}$ & $P$ Value \\
\hline \multicolumn{12}{|c|}{ Province } \\
\hline \multicolumn{12}{|c|}{ Central } \\
\hline $\mathrm{n}$ & 26 & 25 & 11 & 17 & 25 & 13 & 12 & 24 & 1 & 2 & 0.42 \\
\hline$\%$ & 92.90 & 89.30 & 39.30 & 60.70 & 89.30 & 46.40 & 42.90 & 85.70 & 3.60 & 7.10 & \\
\hline \multicolumn{12}{|c|}{ Eastern } \\
\hline $\mathrm{n}$ & 8 & 7 & 6 & 7 & 9 & 5 & 5 & 8 & 2 & 1 & \\
\hline$\%$ & 80.00 & 70.00 & 60.00 & 70.00 & 90.00 & 50.00 & 50.00 & 80.00 & 20.00 & 10.00 & \\
\hline \multicolumn{12}{|c|}{ Northern } \\
\hline $\mathrm{n}$ & 7 & 7 & 6 & 9 & 8 & 6 & 5 & 11 & 2 & 0 & \\
\hline$\%$ & 63.60 & 63.60 & 54.50 & 81.80 & 72.70 & 54.50 & 45.50 & 100.00 & 18.20 & 0.00 & \\
\hline \multicolumn{12}{|c|}{ Southern } \\
\hline $\mathrm{n}$ & 11 & 7 & 9 & 11 & 13 & 4 & 8 & 13 & 2 & 1 & \\
\hline$\%$ & 84.60 & 53.80 & 69.20 & 84.60 & 100.00 & 30.80 & 61.50 & 100.00 & 15.40 & 7.70 & \\
\hline \multicolumn{12}{|c|}{ Western } \\
\hline $\mathrm{n}$ & 7 & 5 & 4 & 7 & 8 & 2 & 3 & 8 & 1 & 1 & \\
\hline$\%$ & 87.50 & 62.50 & 50.00 & 87.50 & 100.00 & 25.00 & 37.50 & 100.00 & 12.50 & 12.50 & \\
\hline \multicolumn{12}{|c|}{ Designation } \\
\hline \multicolumn{12}{|c|}{ Consultant } \\
\hline $\mathrm{n}$ & 6 & 5 & 3 & 6 & 6 & 2 & 4 & 6 & 1 & 0 & 0.46 \\
\hline$\%$ & 85.70 & 71.40 & 42.90 & 85.70 & 85.70 & 28.60 & 57.10 & 85.70 & 14.30 & 0.00 & \\
\hline \multicolumn{12}{|c|}{$\begin{array}{l}\text { General } \\
\text { dentist }\end{array}$} \\
\hline $\mathrm{n}$ & 22 & 21 & 11 & 23 & 26 & 13 & 10 & 26 & 3 & 0 & \\
\hline$\%$ & 81.50 & 77.80 & 40.70 & 85.20 & 96.30 & 48.10 & 37.00 & 96.30 & 11.10 & 0.00 & \\
\hline \multicolumn{12}{|c|}{ Specialist } \\
\hline $\mathrm{n}$ & 31 & 25 & 22 & 22 & 31 & 15 & 19 & 32 & 4 & 5 & \\
\hline$\%$ & 86.10 & 69.40 & 61.10 & 61.10 & 86.10 & 41.70 & 52.80 & 88.90 & 11.10 & 13.90 & \\
\hline \multicolumn{12}{|c|}{$\begin{array}{l}\text { Type of dental } \\
\text { practice }\end{array}$} \\
\hline \multicolumn{12}{|c|}{ Government } \\
\hline $\mathrm{n}$ & 25 & 22 & 14 & 16 & 24 & 9 & 14 & 24 & 0 & 1 & $0.045^{\star}$ \\
\hline$\%$ & 89.30 & 78.60 & 50.00 & 57.10 & 85.70 & 32.10 & 50.00 & 85.70 & 0.00 & 3.60 & \\
\hline \multicolumn{12}{|c|}{ Private clinic } \\
\hline $\mathrm{n}$ & 25 & 19 & 16 & 26 & 29 & 14 & 12 & 28 & 6 & 2 & \\
\hline$\%$ & 86.20 & 65.50 & 55.20 & 89.70 & 100.00 & 48.30 & 41.40 & 96.60 & 20.70 & 6.90 & \\
\hline \multicolumn{12}{|c|}{$\begin{array}{l}\text { University } \\
\text { clinic/hospital }\end{array}$} \\
\hline $\mathrm{n}$ & 9 & 10 & 6 & 9 & 10 & 7 & 7 & 12 & 2 & 2 & \\
\hline$\%$ & 69.20 & 76.90 & 46.20 & 69.20 & 76.90 & 53.80 & 53.80 & 92.30 & 15.40 & 15.40 & \\
\hline \multicolumn{12}{|c|}{ Experience } \\
\hline \multicolumn{12}{|c|}{$>15$ years } \\
\hline $\mathrm{n}$ & 9 & 8 & 8 & 10 & 12 & 7 & 6 & 13 & 2 & 1 & 0.761 \\
\hline \multirow{2}{*}{\multicolumn{12}{|c|}{$1-5$ years }} \\
\hline & & & & & & & & & & & \\
\hline $\mathrm{n}$ & 18 & 16 & 10 & 14 & 15 & 10 & 9 & 18 & 2 & 1 & \\
\hline \multirow{2}{*}{\multicolumn{12}{|c|}{$11-15$ years }} \\
\hline & & & & & & & & & & & \\
\hline $\mathrm{n}$ & 15 & 11 & 7 & 11 & 15 & 3 & 9 & 15 & 1 & 1 & \\
\hline$\%$ & 88.20 & 64.70 & 41.20 & 64.70 & 88.20 & 17.60 & 52.90 & 88.20 & 5.90 & 5.90 & \\
\hline $6-10$ & & & & & & & & & & & \\
\hline $\mathrm{n}$ & 17 & 16 & 11 & 16 & 21 & 10 & 9 & 18 & 3 & 2 & \\
\hline$\%$ & 81.00 & 76.20 & 52.40 & 76.20 & 100.00 & 47.60 & 42.90 & 85.70 & 14.30 & 9.50 & \\
\hline
\end{tabular}


Table 5: Comparison of usage of PPE while performing any dental procedure before and during COVID-19

\begin{tabular}{|c|c|c|c|c|}
\hline \multirow[t]{2}{*}{ Parameters used before COVID-19 } & \multicolumn{3}{|c|}{ Parameters used during COVID-19 } & \multirow[t]{2}{*}{ p-value } \\
\hline & Not used & Used & Total & \\
\hline \multicolumn{5}{|l|}{ Surgical mask } \\
\hline \multicolumn{5}{|l|}{ Not used } \\
\hline $\mathrm{n}$ & 0 & 3 & 3 & 0.057 \\
\hline \multirow{2}{*}{\multicolumn{5}{|c|}{ Used }} \\
\hline & & & & \\
\hline $\mathrm{n}$ & 11 & 56 & 67 & \\
\hline$\%$ & 15.70 & 80.00 & 95.70 & \\
\hline Total & & & & \\
\hline $\mathrm{n}$ & 11 & 59 & 70 & \\
\hline$\%$ & 15.70 & 84.30 & $100.00 \%$ & \\
\hline Examination gloves & & & & \\
\hline Not used & & & & \\
\hline $\mathrm{n}$ & 6 & 6 & 12 & 0.167 \\
\hline$\%$ & 8.60 & 8.60 & 17.10 & \\
\hline Used & & & & \\
\hline $\mathrm{n}$ & 13 & 45 & 58 & \\
\hline$\%$ & 18.60 & 64.30 & 82.90 & \\
\hline Total & & & & \\
\hline $\mathrm{n}$ & 19 & 51 & 70 & \\
\hline$\%$ & 27.10 & 72.90 & 100.00 & \\
\hline Surgical gloves & & & & \\
\hline Not used & & & & \\
\hline $\mathrm{n}$ & 24 & 20 & 44 & 0.1 \\
\hline$\%$ & 34.30 & 28.60 & 62.90 & \\
\hline Used & & & & \\
\hline $\mathrm{n}$ & 10 & 16 & 26 & \\
\hline$\%$ & 14.30 & 22.90 & 37.10 & \\
\hline Total & & & & \\
\hline $\mathrm{n}$ & 34 & 36 & 70 & \\
\hline$\%$ & 48.60 & 51.40 & 100.00 & \\
\hline Head cap & & & & \\
\hline Not used & & & & \\
\hline $\mathrm{n}$ & 14 & 30 & 44 & $0.001^{*}$ \\
\hline$\%$ & 20.00 & 42.90 & 62.90 & \\
\hline Used & & & & \\
\hline $\mathrm{n}$ & 5 & 21 & 26 & \\
\hline$\%$ & 7.10 & 30.00 & 37.10 & \\
\hline Total & & & & \\
\hline $\mathrm{n}$ & 19 & 51 & 70 & \\
\hline$\%$ & 27.10 & 72.90 & 100.00 & \\
\hline Eye protection (face shield) & & & & \\
\hline Not used & & & & \\
\hline$n$ & 5 & 32 & 37 & $0.001^{*}$ \\
\hline$\%$ & 7.10 & 45.70 & 52.90 & \\
\hline Used & & & & \\
\hline $\mathrm{n}$ & 2 & 31 & 33 & \\
\hline$\%$ & 2.90 & 44.30 & 47.10 & \\
\hline Total & & & & \\
\hline $\mathrm{n}$ & 7 & 63 & 70 & \\
\hline$\%$ & 10.00 & 90.00 & 100.00 & \\
\hline Eye protection (goggles) & & & & \\
\hline Not used & & & & \\
\hline $\mathrm{n}$ & 27 & 21 & 48 & 0.23 \\
\hline$\%$ & 38.60 & 30.00 & 68.60 & \\
\hline Used & & & & \\
\hline $\mathrm{n}$ & 13 & 9 & 22 & \\
\hline$\%$ & 18.60 & 12.90 & 31.40 & \\
\hline Total & & & & \\
\hline $\mathrm{n}$ & 40 & 30 & 70 & \\
\hline$\%$ & 57.10 & 42.90 & 100.00 & \\
\hline N95 mask & & & & \\
\hline Not used & & & & \\
\hline $\mathrm{n}$ & 35 & 26 & 61 & $0.001^{*}$ \\
\hline$\%$ & 50.00 & 37.10 & 87.10 & \\
\hline Used & & & & \\
\hline$n$ & 2 & 7 & 9 & \\
\hline$\%$ & 2.90 & 10.00 & 12.90 & \\
\hline Total & & & & \\
\hline $\mathrm{n}$ & 37 & 33 & 70 & \\
\hline$\%$ & 52.90 & 47.10 & 100.00 & \\
\hline Disposable gowns & & & & \\
\hline Not used & & & & \\
\hline $\mathrm{n}$ & 3 & 22 & 25 & $0.001^{*}$ \\
\hline$\%$ & $4.30 \%$ & 31.40 & 35.70 & \\
\hline Used & & & & \\
\hline $\mathrm{n}$ & 3 & 42 & 45 & \\
\hline$\%$ & 4.30 & 60.00 & 64.30 & \\
\hline Total & & & & \\
\hline$n$ & 6 & 64 & 70 & \\
\hline$\%$ & 8.60 & 91.40 & 100.00 & \\
\hline
\end{tabular}

telephone and also reported reducing the number of patients in the waiting area.

On the other hand, based on the data, some dentist did not adhere to the recommended PPE. Noncompliance of dentist to the infection control measures and PPE has been reported in earlier studies. The studies explained that dentist's attitude and knowledge could affect their adherence to guidelines [28], [29]. A study conducted in Jeddah showed that $24 \%$ of the sample did not wear eye protection during patient treatment [29]. Another study done among dentists in Makkah also showed that $11.2 \%$ do not wear masks and few do not wear gown during dental procedures. Recommendation of those studies was that dentist must take training in infection control to increase their knowledge and compliance [30], [31]. A recent study by Khader et al. [32] aimed to assess knowledge, perception, and attitude of dentists toward infection control and COVID-19. Findings showed that onethird of dentists included in their study do not perceive COVID-19 as a serious disease. They also concluded that dentists had limited awareness of the additional infection control measures required to that protect the dental staff and other patients from COVID-19 [32]. Another obstacle that could explain less response in the use of some of the PPE is shortage of the materials, for example, only $47 \%$ are using N95 mask. Based on the responses of participants in the last question in the questionnaire, $35 \%$ reported difficulty in finding the protective materials, especially the N95 mask.

The study has some limitations, first the low sample size that may affect the results. Another limitation is the time span of data collection, it was in a short period ( 3 weeks). The data were collected immediately after the permission of clinics to resume their routine treatment (July 5), therefore, some of the clinics were still undergoing emergency treatments and other clinics recently resumed their work.

This study is considered to be one of the first studies aimed to exploring infection control measures implemented in the dental setting in KSA during COVID-19. More research with bigger sample size is required to have a better understanding of adherence to guidelines by dental clinics and difficulties encountered in implementing cross-contamination measures. Further studies could assess the knowledge and attitude of dentists toward infection control protocols and COVID-19.

The evidence shows that majority of dentists working in KSA are following recommended measures to minimize the spread of COVID-19. Some dentists modified their PPE used during the pandemic. On the other hand, other dentists were not following strict infection control measures, it is required to increase awareness and provide training to dentist to increase compliance [31]. 


\section{Acknowledgment}

The project was supported by Deanship of Graduate Studies and Scientific Research at Dar Al Uloom University, Riyadh, KSA.

\section{References}

1. Yuen KS, Ye ZW, Fung SY, Chan CP, Jin DY. SARS-CoV-2 and COVID-19: The most important research questions. Cell Biosci. 2020;10(1):40. https://doi.org/10.1186/ s13578-020-00404-4

PMid:32190290

2. Tang D, Comish P, Kang R. The hallmarks of COVID-19 disease. PLoS Pathog. 2020;16(5):e1008536. https://doi.org/10.1371/ journal.ppat.1008536 PMid:32442210

3. Ortiz-Prado E, Simbaña-Rivera K, Gómez-Barreno L, RubioNeira M, Guaman LP, Kyriakidis NC, et al. Clinical, molecular, and epidemiological characterization of the SARS-CoV-2 virus and the Coronavirus disease 2019 (COVID-19), a comprehensive literature review. Diagn Microbiol Infect Dis. 2020;98(1):115094. https://doi.org/10.20944/preprints202004.0283.v1 PMid:32623267

4. Zhang LP, Wang M, Wang $\mathrm{Y}$, Zhu J, Zhang N. Focus on a 2019-novel Coronavirus (SARS-CoV-2). Future Microbiol. 2020;15:905-18. https://doi.org/10.2217/fmb-2020-0063 PMid:32524843

5. Rodriguez-Morales AJ, Bonilla-Aldana DK, Balbin-Ramon GJ, Rabaan AA, Sah R, Paniz-Mondolfi A, et al. History is repeating itself: Probable zoonotic spillover as the cause of the 2019 novel Coronavirus Epidemic. Infez Med. 2020;28(1):3-5. PMid:32009128

6. Tan W, Zhao X, Ma X, Wang W, Niu P, Xu W, et al. A novel Coronavirus genome identified in a cluster of pneumonia casesWuhan, China 2019-2020. China CDC Wkly. 2020;2(4):61-2. https://doi.org/10.46234/ccdcw2020.017

7. Zhu N, Zhang D, Wang W, Li X, Yang B, Song J, et al. A nove Coronavirus from patients with pneumonia in China, 2019. N Engl J Med. 2020;382(8):727-33. PMid:31978945

8. Mahase E. China Coronavirus: WHO declares international emergency as death toll exceeds 200. BMJ. 2020;368:m408. https://doi.org/10.1136/bmj.m408

PMid:32005727

9. World Health Organization. WHO Timeline-COVID-19. Geneva: World Health Organization; 2020. Available from: https://www. who.int/news-room/detail/27-04-2020-who-timeline---covid-19. [Last accessed on 2020 Jun 25]. https://doi.org/10.20944/ preprints202007.0051.v1

10. Guo G, Ye L, Pan K, Chen Y, Xing D, Yan K, et al. New insights of emerging SARS-CoV-2: Epidemiology, etiology, clinical features, clinical treatment, and prevention. Front Cell Dev Biol. 2020;8:410. https://doi.org/10.3389/fcell.2020.00410 PMid:32574318

11. Huang $\mathrm{C}$, Wang $\mathrm{Y}$, Li X, Ren L, Zhao J, Hu Y, et al. Clinical features of patients infected with 2019 novel Coronavirus in Wuhan, China. Lancet. 2020;395(10223):497-506. https://doi. org/10.1016/s0140-6736(20)30183-5

\section{PMid:31986264}

12. World Health Organization. Report of the WHO-China Joint Mission on Coronavirus Disease 2019 (COVID-19). Geneva: World Health Organization; 2020.

13. Rothan HA, Byrareddy SN. The epidemiology and pathogenesis of Coronavirus disease (COVID-19) outbreak. J Autoimmun. 2020;109:102433. https://doi.org/10.1016/j.jaut.2020.102433 PMid:32113704

14. Singhal T. A review of Coronavirus disease-2019 (COVID-19). Indian J Pediat. 2020;87(4):281-6.

PMid:32166607

15. Wang D, Hu B, Hu C, Zhu F, Liu X, Zhang J, et al. Clinical characteristics of 138 hospitalized patients with 2019 novel Coronavirus-infected pneumonia in Wuhan, China. JAMA. 2020;323(11):1061-9. https://doi.org/10.1001/jama.2020.1585 PMid:32031570

16. World Health Organization. Modes of Transmission of Virus Causing COVID-19: Implications for IPC Precaution Recommendations: Scientific Brief, 27 March 2020. Geneva: World Health Organization; 2020.

17. European Centre for Disease Prevention and Control. Infection Prevention and Control and Preparedness for COVID-19 in Healthcare Settings, Stockholm; 2020.

18. Morawska L, Tang JW, Bahnfleth W, Bluyssen PM, Boerstra A Buonanno G, et al. How can airborne transmission of COVID-19 indoors be minimised? Environ Int. 2020;142:105832. https:// doi.org/10.1016/j.envint.2020.105832 PMid:32521345

19. Zhang R, Li Y, Zhang AL, Wang Y, Molina MJ. Identifying airborne transmission as the dominant route for the spread of COVID-19. Proc Natl Acad Sci USA. 2020;117(26):14857-63. https://doi.org/10.1073/pnas.2009637117 PMid:32527856

20. Su J. Aerosol transmission risk and comprehensive prevention and control strategy in dental treatment. Zhonghua Kou Qiang Yi Xue Za Zhi. 2020;55(4):229-34 PMid:32268623

21. Zemouri C, de Soet $H$, Crielaard W, Laheij A. A scoping review on bio-aerosols in healthcare and the dental environment. PLoS One. 2017;12(5):e0178007. https://doi.org/10.1371/journal. pone. 0178007 PMid:28531183

22. Meng L, Hua F, Bian Z. Coronavirus disease 2019 (COVID-19): Emerging and future challenges for dental and oral medicine. J Dent Res. 2020;99(5):481-7. https://doi. org/10.1177/0022034520914246 PMid:32162995

23. Peng $X, X u X$, Li Y, Cheng L, Zhou X, Ren B. Transmission routes of 2019-nCoV and controls in dental practice. Int J Ora Sci. 2020;12(1):9. https://doi.org/10.1038/s41368-020-0075-9 PMid:32127517

24. Ministry of Health. Guidance for Reopening Dental Services in Governmental and Private Sectors during COVID-19 Pandemic. Saudi Arabia: Ministry of Health; 2020.

25. Consolo U, Bellini $P$, Bencivenni D, lani C, Checchi V Epidemiological aspects and psychological reactions to COVID-19 of dental practitioners in the Northern Italy districts of modena and reggio emilia. Int $\mathrm{J}$ Environ res Public Health. 2020;17(10):3459. https://doi.org/10.3390/ijerph17103459 PMid:32429193

26. Laheij AM, Kistler JO, Belibasakis GN, Välimaa H, de Soet JJ Healthcare-associated viral and bacterial infections in dentistry. J Oral Microbiol. 2012;4(1):17659. https://doi.org/10.3402/jom. v4i0.17659 


\section{PMid:22701774}

27. Fiorillo L, Cervino G, Matarese M, D'Amico C, Surace G, Paduano V, et al. COVID-19 surface persistence: A recent data summary and its importance for medical and dental settings. Int J Environ Res Public Health. 2020;17(9):3132. https://doi. org/10.3390/ijerph17093132

PMid:32365891

28. Jibreen S, Dababneh R, Khouri A. Compliance with the use of personal protective equipment among dentists working at the royal medical services. J R Med Serv. 2009;16:74-8.

29. AlAhdal A, Aljehani W, Ali G, Bayoumi A. Knowledge, attitude and practice of infection control measures in private dental clinics in Jeddah, Saudi Arabia. Int J Dent Oral Health. 2019;5(1):1-6. https://doi.org/10.16966/2378-7090.286
30. Mandourh MS, Alhomaidhi NR, Fatani NH, Alsharif AS, Ujaimi GK, Khan G. Awareness and implementation of infection control measures in private dental clinics, Makkah, Saudi Arabia. Int J Infect Control. 2017;13(1):1-14.

31. Mutters NT, Hägele $U$, Hagenfeld D, Hellwig E, Frank $U$. Compliance with infection control practices in an university hospital dental clinic. GMS Hyg Infect Control. 2014;9(3):Doc18. PMid:25285262

32. Khader Y, Al Nsour M, Al-Batayneh OB, Saadeh R, Bashier H, Alfaqih M, et al. Dentists' awareness, perception, and attitude regarding COVID-19 and infection control: Cross-sectional study among jordanian dentists. JMIR Public Health Surveill. 2020;6(2):e18798. https://doi.org/10.2196/18798

PMid:32250959 